\title{
The Challenges in Marketing a Tourist Destination, a Case Study of Sierra Leone
}

\author{
Philip Samuel Kongoley - MIH \\ * Milton Margai College of Education and Technology, Faculty of Business Administration and Management, Congo Cross Campus, Freetown Sierra \\ Leone \\ DOI: 10.29322/IJSRP.11.09.2021.p11728 \\ http://dx.doi.org/10.29322/IJSRP.11.09.2021.p11728
}

\begin{abstract}
This paper attempts to investigate the challenges in marketing a tourist destination, a case study of Sierra Leone. This paper offers a comprehensive understanding of the concept of tourist destination marketing and challenges. It is descriptive as it describes destination marketing concept and opinion of respondents on the challenges of marketing destination.200 respondents from the Ministry of Tourism and Cultural Affairs and National Tourist Board were selected using a simple random sampling technique. A structured questionnaire was administered among the respondents and only 200 was returned filled which form the bases for analysis. The collected data was analyzed by the used of Statistical Packages for the Social Sciences and Garrett ranking. It was found out that Sierra Leone cannot attract tourist due to inadequate fund for marketing plans as a major challenge. It is recommended that the government of Sierra Leone to ensure that adequate funding is provided for the marketing and promotion of the country if it to be a tourist destination.
\end{abstract}

Index Terms- Destination, marketing, tourism, tourist, promotion and strategies

\section{INTRODUCTION}

$\mathrm{M}$ ost of the destinations worldwide are competing for more and more tourist, in which their image as a tourism destination plays an important role. Marketing is a method that can help the destination to create a desired image and influence tourists to visit the destination on the bases of that desired image. In addition, marketing is the process of communicating one's product to potential buyers. Research has shown that nations that market themselves internationally as good tourist destinations have affianced in a severe competition to pull more and more tourists into their respective destinations. Thus, the role of marketing is attracting more and more tourists to a destination. Therefore, destination marketing is becoming a very hot and burning topic nowadays in tourism industry.

Tourism has been traditionally viewed as a great force in promoting understanding among nations and within the national boundaries facilitating emotional integration. However, its economic importance is less commonly understood. It is only in the rent years, in particular the latter half of the 20 th century that tourism has been accepted as an important catalyst for economic development. It is in terms of its contribution to employment generation, foreign exchange earnings, income generation and output growth that tourism has significant impact on the economy of many developed and developing countries. The World Tourism organization (WTO) sees tourism as an activity by people who travel outside of their customary neighbourhood either for leisure, business, or for medical purposes for a period not exceeding one year. Some tourism scholars see tourism as the temporary movement of individuals away from their normal surroundings, and the activities undertaken during their stay in the new destination, as well as the facilities made to cater for the tourist needs. Tourists are drawn to a certain tourism destination because of its attractiveness that reflects the feelings of the tourists regarding the destination perceived ability to meet their needs. Thus, the more a certain destination meets the tourist's needs, the more it is seen to be attractive, and consequently its popularity grows. It is imperative that the sustainable tourism development concept be adopted in all tourism destinations in order to appropriately cater for the needs of the travellers and the host destinations while enhancing and protecting opportunities for the future.

Tourism development occupies an irreplaceable position in the formulation of policy in all countries because of its benefits for the local people in respect to the social, economic and environmental concerns. Tourist destinations compete for tourists at tourism market leading to a sharp competitive struggle (Zygmunt 2013). The main objective of regional and governments and the tourism industry stakeholders is to succeed by enhancing the competitiveness of their destination. The tourism industry is in most countries, the largest player in the economic sectors, therefore, it is important factor in the development of any region, and more so, in European countries. By its nature, it contributes to the stability of both regional and local economies because of its multiplier effect which helps create business opportunities in the activities that go into making the tourist comfortable as well as influencing the creation of employment in the region.

A tourist destination is a geographical location which has the necessary components to attract tourists and meet their needs. It comprises of different components such as: attractions which motivate tourist to visit the destination and consist of the natural, historical and man-made. Amenities are range of supporting facilities and services like accommodation, food, entertainment and recreation which are required by tourist at the destination. Access in terms of development and maintenance of transport which provides the link to the tourist destination as well as the tourist attractions at the destination and ancillary services which are provided to customers and industry by the destination through a local tourist board. The destination must make use of its abilities, 
resources and opportunities from the environment in order to create the maximum value and therefore be successful. The tourist destination can meet the needs of its consumers better than its competitors by analyzing the marketing environment (M. Djurica 2010).

Tourists are drawn to a certain tourism destination because of its attractiveness that reflects the feelings of the tourists regarding the destination perceived ability to meet their needs. Thus, the more a certain destination meets the tourist's needs, the more it is seen to be attractive and consequently its popularity grows. The ability to meet the tourist needs include the attributes of the destination or the components that make the given destination (Biganoa,et al. 2004). Therefore, the people evaluate the attractiveness of a destination and make their choices accordingly. Thus, the attractiveness of a destination is the main factor in getting the tourist to visit and spend time at a given destination. Consequently, the value of a destination is the pulling it has on visitors. If a destination does not have the attractiveness value it cannot attract tourist, and therefore, there is no need for putting up tourist facilities and services. At global level the following destinations have been ranked as the ten most visited destinations by tourists in the world in 2020 .

\section{LITERATURE REVIEWS}

\subsection{An Overview of Destination Marketing}

First of all, a clear distinction between place marketing and destination marketing should be made. As opposed to destination marketing, the broader field of place marketing is not limited to increasing the number of tourist arrivals. It rather has an effect on more expansive areas like regional and urban development, international relations, country positioning, as well as economic growth. Correspondingly, Kotler (1993), a pioneer and leader in marketing research issues, published a book on marketing places, where he examines how investment, industry and tourism can be attracted to cities, states and nations. Hence, place marketing basically embraces four core activities. To begin with it engages in designing the appropriate mix of community features and services. Furthermore, attractive incentive for the existing as well as potential buyers and users of the place's goods and services are set. These goods and services then have to be delivered in an efficient way. Also, the respective place's values and image have to be promoted, so that potential consumers and users are aware of all the advantages (Kotler 1993). Although it is not the only nor the most important aspect, the importance of tourism for place marketing should be under estimated. It must be considered as integral part of place marketing, because it supports and leads the development of a place brand (Cameron 2007.pp 80-81). Against the above discussed background, now a definition of actual destination marketing shall be given. According to the United Nations World Tourism Organization (UNWTO 2004,p,10), destination marketing, "covers all the activities and processes to bring buyers and sellers together, focuses on responding to consumer demands and competitive positioning, is a continuous coordinated set of activities associated with efficient distribution of products to high potential markets, involves making decisions about the product, branding, the price, market segmentation, promotion and distribution"
Destination marketing facilities the success of tourism policy, which should ideally be in line with the strategic plan for overall regional development (Buhalis 2000.p.97). Baker and Cameron ( 2007) point out that destination marketing involves using tourism for reasons like improving the overall image of the area in order to attract industry, increasing infrastructure that can also be used by the local community, achieving changes in the environment, or giving the locals more pride in their area. Thereby, tourism is often used as a means to an end rather than an end in itself. Anyhow, the fact that marketing has the power to positively influence destination development is widely acknowledged.

\subsection{The Role of Marketing}

\subsubsection{Product Development}

With regard to tourism, this study refers to product as a tourist destination. "a product is anything that is offered to the market to satisfy a want or need" The author holds that tourism product is complex in comparison to conventional products. For instance, a new destination can be viewed as a new product, a tour operator package etc. In respect of tourism products, the author underscores that when consumers buy tourism products they are generally buying features of the perceived quality, standard or general image. Further, the product's (place) image and its value may be further projected through the use of band image which act, as a cue. Notably, other tourism studies refer to various services and activities as product. For instance, adventure, sun and beach can be categorized as products offered in a given destination. For the purpose of this study, the researcher generalize place as a product for ease of reference. Naturally selling intangible product is far challenging than selling retail product as holiday package. It is obvious that more skills are needed to sell tourism products, as more effort is needed in convincing consumers based on imaginary assumption as the sun and beach available in a given destination. Decisions made on products depended on the country origin of the product as the country origin signifies the quality of the product.

\subsubsection{Place Marketing}

This section presents the key constructs of promotion aspects under the context of place marketing. The section commence by briefly addressing the classic models of marketing mix or popularly known as the four Ps (promotion, place, price and product).It should be noted that focus of this study is centered on promotion strategy significant to this study. Further, other promotional techniques relevant to tourism perspective are addressed. The central objective here is to review literature on effects of country image cues and their relation to promotion strategy. The models are further analysed in the empirical section to compare and contrast with the collected data from interviews. Developing any of the four techniques depends on the objectives of the marketer in question.

\subsubsection{Pricing}

Pricing encapsulates discounts, commissions, surcharges and extras that are employed in marketing, when promoting a destination in comparison to other places. It is common for the place marketers to offering intriguing trial packages in winning new customers. As most countries realize the potential of tourism to their economies, price wars are increasing in the market place as promoters are striving for a win-win situation. 


\subsubsection{Place}

In this context, place does not necessarily refers to a tourism destination. With regard to promotion mix a place implies the unit for product distribution. In other words, the methods promoters employ on product distribution to the market. For instance, in promoting tourism abroad, it is cited that a country engaging in promoting tourist abroad, should secure, a representative (channels) abroad that will cater for the target market. This is suitable for a country with enough funds to establish a representative office abroad than anchoring on travel intermediaries whose primary objective is to maximize their own business. Further, it is inclined that these representative offices are positioned to meet face to face with the consumers and correct immediately the distorted perception Kotler et al (1993). In respect of conventional products, place which implies marketing channels is a significant strategy for a manufacturer. Corporations exporting products abroad normally secure reliable distributor to ensure sustainability of brand, quality and service Kotler (2000).For countries engaging in building image in the target market, it is recommended to secure reliable representatives who will maintain brand equity avoiding endangering a country profile. In light of promoting a country, the researcher adopts a concept from Wells and Wint (2000), to broaden the discussion on destination marketing. Thus, marketing a country encompasses three promotion activities, image building, and investment generation and investor service. However, the authors marketing monograph acknowledges combinations of the three promotion strategies depending on the objectives of a particular country Wells and Wint $(200,159)$. For instance, a country that has strived to change its policies in attracting foreign investors by ease "ownership regulations" should focus on image building in encouraging investor on credibility.

\subsubsection{Promotion}

This section addresses promotion strategy that can be used by place marketers to reach its target market. Promotion strategy refers to an activity of marketers communicating with target audience in the various or selected market. In light of promotion there are various modes of promotion strategies and tools which include sales promotion, direct selling, advertising, public relation and personal selling Kotler et al (1993.P.152) shares the same notion by underlining some important aspects that will ease confusion when creating a message and image of place. Transmission forms link between images held by persons and those projected by places. It is therefore argued that place marketers should understand what image people hold prior to embarking on promotion strategy

\section{Methodology}

The purpose of this paper can be exploratory, descriptive and explanatory or policy oriented. These categories are not mutually exclusive; they are a matter of emphasis. As any research paper will change and develop over time, one can identify more than one purpose. These four types of research are discussed below.

\subsection{Research Design}

This study is designed as a descriptive case study. The researcher preferred the method because of its ability to describe a situation and its minimum bias in the collection of data. This descriptive design involves large numbers of persons, and describes population characteristics by the selection of unbiased sample. It involves using questionnaires and sometimes interview tests and generalizing the results of the sample to the population from which it is drawn. Descriptive design is the most frequently used method of collecting information about people's attitudes; opinions and habits on social issues and such studies usually do not involve hypothesis testing.

\subsection{Population}

The population for this study is an entire group of individuals, events or objects with some common observable characteristics. The study population included staff of the Ministry of Tourism and Cultural Affairs and National Tourist Board who is charged with the responsibility of marketing Sierra Leone as a tourist destination.

\subsection{Sampling Frame}

A sampling frame is a list, directory or index of cases from which a sample can be selected. The sampling frame for this study was from the directory of the two institutions which includes list of all staff members.

\subsection{Sampling Technique}

A sample is part of the target (or accessible) population that has been procedurally selected to represent it. The area of study as Sierra Leone was selected. The target population composed of staff of the two selected institutions were selected using a simple random sampling techniques.

\subsection{Sample Size}

Sample size is an important feature of any empirical study in which the goal is to make inferences about a population. To obtain the sample size, the researcher selected 120 staff from the Ministry of Tourism and Cultural Affairs and 80 from National Tourist Board all in Freetown so the 200 respondents formed the sample size.

\subsection{Research Instruments}

The main research instrument for this study was a structured questionnaire for all staff of the above mentioned institutions. The questionnaire consisted of both open and close questions to ease analysis of data. It consisted of questions gearing toward sounding their opinions about the challenges they are faced with in marketing Sierra Leone as a tourist destination. All questions were with options and it was left to the respondents to only select the appropriate one for him or her.

\subsection{Data Collection Procedure}

The source of data was mainly primary as this study was an original study. As indicated earlier a close and open - ended questionnaire for the staff was used as a main instrument to collect data. The questionnaire distribution was facilitated by the researcher who also assisted in the collection process. The whole of this exercise was done for a period of three months due to the Covid - 19 restrictions

\subsection{Data Processing and Analysis}

Data collected was analyzed quantitatively using the simple percentage method, Statistical Packages for the Social Sciences and Garrett ranking. Before starting the analysis process, the researcher processed the data by editing, categorizing and coding it appropriately. 


\section{RESUlTS AND DisCUSSIONS}

Tables below shows the general characteristics of the respondents in terms of gender, age, length of service, educational level, sector, years of experience, number of employees and monthly income

Table 4.2. Gender of respondents

\begin{tabular}{|l|l|l|}
\hline & Frequency & Percent \\
\hline Male & 120 & 60.0. \\
Female & 80 & 40.0 \\
Total & 200 & 100.0 \\
\hline
\end{tabular}

\section{Source: Field Survey 2021}

The table above reveals that $60 \%$ of the respondents contacted for this study are males and $40 \%$ are females. Meaning majority of the respondents contacted for this are males. Reason being that the tourism industry managerial levels is predominantly occupied by males.

Table 4.3. Age of respondents

\begin{tabular}{|l|l|l|}
\hline & Frequency & Percent \\
\hline $18-30$ years & 20 & 10.0 \\
$31-42$ years & 100 & 50.0 \\
$43-55$ years & 50 & 25.0 \\
56 years and above & 30 & 15.0 \\
Total & 200 & 100.0 \\
\hline
\end{tabular}

Source: Field Survey 2021

The table above reveals that $10 \%$ of the respondents contacted for this study are within the age bracket of $18-30$ years, $50 \%$ are within $31-42$ years, $25 \%$ are within $43-55$ years and $15 \%$ within 56 years and above. Meaning majority of the respondents contacted for this study are within the age bracket of $43-55$ years.

\section{Table 4.4. Length of service}

\begin{tabular}{|l|l|l|}
\hline & Frequency & Percent \\
\hline $1-5$ years & 30 & 15.0 \\
6 - 10 years & 25 & 12.5 \\
$11-15$ years & 100 & 50.0 \\
$16-20$ years & 20 & 10.0 \\
21 years and above & 25 & 12.5 \\
Total & 200 & 100.0 \\
\hline
\end{tabular}

Source: Field Survey 2021

The table above shows that $15 \%$ of the respondents contacted for this study had worked with any of the sectors in the tourism industry between $1-5$ years, $12.5 \%$ between $6-10$ years, $50 \%$ between $11-15$ years, $10 \%$ between $16-20$ years and $12.5 \%$ between 21 years and above. Meaning majority of the respondents contacted had worked in any of the tourism sectors above 10 years.

Table 4.5. Educational level

\begin{tabular}{|l|l|l|}
\hline & Frequency & Percent \\
\hline Below first degree & 20 & 10.0 \\
First degree & 120 & 60.0 \\
Master & 50 & 25.0 \\
Doctorate & 10 & 5.0 \\
Total & 200 & 100.0 \\
\hline
\end{tabular}

Source: Field Survey 2021

The table above shows that $10 \%$ of the respondents contacted for this study are holders of qualifications below first degree, 60 $\%$ are holders of the first degree, $25 \%$ are holders of the master degree and $5 \%$ are holders of a doctorate degree. Meaning majority of the respondents contacted for this study are holders of first degree in various disciplines.

Table 4.6. Sector of respondents

\begin{tabular}{|l|l|c|}
\hline & Frequency & Percent \\
\hline Ministry & 120 & 60.0 \\
National Tourist Board & 80 & 40.0 \\
Total & 200 & 100.0 \\
\hline
\end{tabular}

Source: Field Survey 2021

The table above reveals that $60 \% \%$ of the respondents contacted for this study are from the Ministry of Tourism and Cultural Affairs and $40 \%$ are from the National Tourist Board. Meaning majority of the respondents are from the accommodation sector.

Table 4.7. Occupation of respondents

\begin{tabular}{|l|l|l|}
\hline & Frequency & Percent \\
\hline Director & 60 & 30.0 \\
Manager & 40 & 20.0 \\
Supervisor & 20 & 10.0 \\
Professional & 70 & 35.0 \\
Others & 10 & 5.0 \\
Total & 200 & 100.0 \\
\hline
\end{tabular}

Source: Field Survey 2021

The table above reveals that $30 \%$ of the respondents contacted for this study are directors, $20 \%$ are managers, $10 \%$ are supervisors, $35 \%$ are professionals and $5 \%$ are others. Meaning majority of the respondents are professionals. Reason being that the tourism industry is a professional sector. 
Table 4.9. Years of existence of the sector

\begin{tabular}{|l|l|l|}
\hline & Frequency & Percent \\
\hline 1 - 10 years & 40 & 20.0 \\
$11-20$ years & 130 & 65.0 \\
$21-30$ years & 15 & 7.5 \\
$31-40$ years & 10 & 5.0 \\
Over 41 years & 5 & 2.5 \\
Total & 200 & 100.0 \\
\hline
\end{tabular}

\section{Source: Field Survey 2021}

The table above shows that $20 \%$ of the respondents contacted for this study are a sector that is between $1-10$ years of existence, $65 \%$ between $11-20$ years, $7.5 \%$ between $21-30$ years, $5 \%$ between $31-40$ years and $2.5 \%$ over 41 years. Meaning majority of the respondents are from a sector between 11- 20 years of existence. Reason being that many of these businesses came into existence after the rebel war in Sierra Leone.

Table 4.9. Approximate number of employees

\begin{tabular}{|l|l|l|}
\hline & Frequency & Percent \\
\hline $1-10$ & 40 & 20.0 \\
$11-20$ & 60 & 30.0 \\
$21-30$ & 70 & 35.0 \\
$31-40$ & 15 & 7.5 \\
$41-50$ & 10 & 5.0 \\
51 and above & 5 & 2.5 \\
Total & 200 & 100.0 \\
\hline
\end{tabular}

Source: Field Survey 2021

The table above shows that $20 \%$ of the respondents contacted for this study are from a sector with approximately number of employees between $1-10,30 \%$ between $11-20,35 \%$ between $21-30,7.5 \%$ between $31-40,5 \%$ between $41-50$ and $2.5 \%$ between 51 and above. Meaning majority of the respondents are from a sector with approximately number of employees between
$21-30$. Reason being that majority of the tourism businesses are small size businesses.

Table 4.10. Monthly income of respondents

\begin{tabular}{|l|l|l|}
\hline & Frequency & Percent \\
\hline Less than Le 500,000 & 5 & 2.5 \\
Le 500,000 - Le 1,000,000 & 10 & 5.0 \\
Le 1,000,000 - Le 2,000,000 & 45 & 22.5 \\
Le 2,000,000 - Le 3,000,000 & 80 & 40.0 \\
Le 4,000,000 and above & 60 & 30.0 \\
Total & 200 & 100.0 \\
\hline
\end{tabular}

Source: Field Survey 2021

The table above reveals that $2.5 \%$ of the respondents contacted for this study are earning less than Le 500,000, $5 \%$ are earning between Le 500,000 - Le 1,000,000, $22.5 \%$ are earning between Le 1,000,000 - Le 2,000,000, $40 \%$ are earning between Le 2,000,000 - Le 3,000,000 and 30\% are earning Le 4,000,000 and above. Meaning majority of the respondents are earning between Le 2,000,000 - Le 3,000,000.

Below are responses from respondents in relations to the various statements in terms of $1=$ Not Satisfactory, $2=$ Highly not Satisfactory, $3=$ Neutral, $4=$ Satisfactory and $5=$ Highly Satisfaction

Table 4.11. Challenges in Marketing a Destination

\begin{tabular}{|l|l|l|l|l|l|l|l|}
\hline & & NS & HNS & N & S & HS & TOTAL \\
\hline 1 & The solution of destination marketing & 5 & 10 & 120 & 40 & 25 & $\mathbf{2 0 0}$ \\
& & $(2.5 \%)$ & $(5 \%)$ & $(60 \%)$ & $(20 \%)$ & $(12.5 \%)$ & $(\mathbf{1 0 0 \%})$ \\
\hline 2 & Tourism infrastructures & 80 & 70 & 5 & 20 & 25 & $\mathbf{2 0 0}$ \\
& & $(40 \%)$ & $(35 \%)$ & $(2.5 \%)$ & $(10 \%)$ & $(12.5 \%)$ & $(\mathbf{1 0 0})$ \\
\hline 3 & Tourism globalization & 70 & 75 & 15 & 30 & 10 & $\mathbf{2 0 0}$ \\
& & $(35 \%)$ & $(37.5 \%)$ & $(7.5 \%)$ & $(15 \%)$ & $(5 \%)$ & $(\mathbf{1 0 0} \%)$ \\
\hline 4 & Taxes & 80 & 50 & 10 & 35 & 25 & $\mathbf{2 0 0}$ \\
& & $(40 \%)$ & $(25 \%)$ & $(5 \%)$ & $(17.5 \%)$ & $(12.5 \%)$ & $(\mathbf{1 0 0} \%)$ \\
\hline 5 & Tourism protection and safety & 80 & 90 & 5 & 10 & 15 & $\mathbf{2 0 0}$ \\
& & $(40 \%)$ & $(45 \%)$ & $(2.5 \%)$ & $(5 \%)$ & $(7.5 \%)$ & $(\mathbf{1 0 0})$ \\
\hline 6 & Travel marketing & 70 & 60 & 20 & 35 & 15 & $\mathbf{2 0 0}$ \\
\hline
\end{tabular}

This publication is licensed under Creative Commons Attribution CC BY. 


\begin{tabular}{|c|c|c|c|c|c|c|c|}
\hline & & $(35 \%)$ & $(30 \%)$ & $(10 \%)$ & $(17,5 \%)$ & $(7.5 \%)$ & $(\mathbf{1 0 0 \%})$ \\
\hline 7 & Inadequate fund for marketing plans & $\begin{array}{l}90 \\
(45 \%)\end{array}$ & $\begin{array}{l}70 \\
(35 \%)\end{array}$ & $\begin{array}{l}5 \\
(2.5 \%)\end{array}$ & $\begin{array}{l}20 \\
(10 \%)\end{array}$ & $\begin{array}{l}15 \\
(7.5 \%)\end{array}$ & $\begin{array}{l}200 \\
(100 \%)\end{array}$ \\
\hline 8 & Lacked of trained and qualified marketers & $\begin{array}{l}60 \\
(30 \%)\end{array}$ & $\begin{array}{l}70 \\
(35 \%)\end{array}$ & $\begin{array}{l}15 \\
(7.5 \%)\end{array}$ & $\begin{array}{l}25 \\
(12.5 \%)\end{array}$ & $\begin{array}{l}30 \\
(15 \%)\end{array}$ & $\begin{array}{l}200 \\
(100 \%)\end{array}$ \\
\hline 9 & Lacked of marketing strategies & $\begin{array}{l}90 \\
(45 \%)\end{array}$ & $\begin{array}{l}60 \\
(30 \%) \\
\end{array}$ & $\begin{array}{l}20 \\
(10 \%)\end{array}$ & $\begin{array}{l}20 \\
(10 \%) \\
\end{array}$ & $\begin{array}{l}10 \\
(5 \%)\end{array}$ & $\begin{array}{l}200 \\
(100 \%)\end{array}$ \\
\hline 10 & Absent of a national carrier & $\begin{array}{l}100 \\
(50 \%)\end{array}$ & $\begin{array}{l}50 \\
(25 \%)\end{array}$ & $\begin{array}{l}5 \\
(2.5 \%)\end{array}$ & $\begin{array}{l}25 \\
(12.5 \%)\end{array}$ & $\begin{array}{l}20 \\
(10 \%)\end{array}$ & $\begin{array}{l}200 \\
(100 \%)\end{array}$ \\
\hline
\end{tabular}

The table above reveals that $2.5 \%$ of the respondents indicated not satisfactory with the solution of destination marketing, $5 \%$ indicated highly not satisfactory, 60\% indicated neutral, $20 \%$ indicated satisfactory and $12.5 \%$ indicated highly satisfactory. Meaning majority of the respondents indicated neutral with the solution of destination marketing as one of the challenges. $40 \%$ of the respondents indicated not satisfactory with tourism infrastructures, $35 \%$ indicated highly not satisfactory, $2.5 \%$ indicated neutral, $15 \%$ indicated satisfactory and $5 \%$ indicated highly satisfactory. Meaning majority of the respondents indicated not satisfactory with tourism infrastructures as one of the challenges. $40 \%$ of the respondents indicated not satisfactory with taxes, $2.5 \%$ indicated highly not satisfactory,5\% indicated neutral, $17.5 \%$ indicated satisfactory and $12.5 \%$ indicated highly satisfactory. Meaning majority of the respondents indicated not satisfactory with taxes as one of the challenges. $40 \%$ of the respondents indicated not satisfactory with tourism protection and safety, $45 \%$ indicated highly not satisfactory, $2.5 \%$ indicated neutral,5\% indicated satisfactory and $7.5 \%$ indicated highly satisfactory. Meaning majority of the respondents indicated highly not satisfactory with tourism protection and safety as one of the challenges.35\% of the respondents indicated not satisfactory with travel marketing, $30 \%$ indicated highly not satisfactory, $10 \%$ indicated neutral, $17.5 \%$ indicated satisfactory and $7.5 \%$ indicated highly satisfactory. Meaning majority of the respondents indicated not satisfactory with travel marketing as one of the challenges. $45 \%$ of the respondents indicated not satisfactory with inadequate fund for marketing plans, $35 \%$ indicated highly not satisfactory, $2.5 \%$ indicated neutral, $10 \%$ indicated satisfactory and $7.5 \%$ indicated highly satisfactory. Meaning majority of the respondents indicated not satisfactory with inadequate fund for marketing plans as one the challenges. $30 \%$ of the respondents indicated not satisfactory with lacked of trained and qualified marketers, $35 \%$ indicated highly not satisfactory, $7.5 \%$ indicated neutral, $12.5 \%$ indicated satisfactory and $15.5 \%$ indicated highly satisfactory. Meaning majority of the respondents indicated highly not satisfactory with lacked of trained and qualified marketers as one of the challenges. $45 \%$ of the respondents indicated not satisfactory with lacked of marketing strategies,30\% indicated highly not satisfactory, $10 \%$ indicated neutral, $10 \%$ indicated satisfactory and 5\% indicated highly satisfactory. Meaning majority of the respondents indicated not satisfactory with lacked of marketing strategies as one of the challenges. $50 \%$ of the respondents indicated not satisfactory with absent of a national carrier, $25 \%$ indicated highly not satisfactory, $2.5 \%$ indicated neutral,12.5\% indicated satisfactory and $10 \%$ indicated highly satisfactory. Meaning majority of the respondents indicated not satisfactory with absent of a national carrier as one of the challenges.

Table 4.12. Garrett Ranking on Challenges

\begin{tabular}{|l|l|l|}
\hline FACTOR & MEAN & RANK \\
\hline 1 & 27.26 & 10 \\
2 & 43.06 & 9 \\
3 & 55.57 & 1 \\
4 & 54.55 & 6 \\
5 & 55.5 & 2 \\
6 & 54.6 & 5 \\
7 & 55.34 & 3 \\
8 & 49.56 & 8 \\
9 & 51.55 & 7 \\
10 & 55.02 & 4 \\
\hline
\end{tabular}

Travel marketing

Absent of a national carrier

Inadequate fund for marketing plans

The solution of destination marketing

Tourism infrastructures

Tourism protection safety

Lacked of trained marketers

Tourism globalization

Taxes

Lacked of strategies

\section{Source: Field Survey 2021}

The table above reveals how the factors were ranked by the respondents contacted for this study under the challenges of marketing a destination. Inadequate fund for marketing plans was ranked first with Garrett mean score of 55.57 followed by tourism infrastructures with Garrett mean score of 55.5,lacked of trained marketers with Garrett mean score of 55.34, lacked of strategies with Garrett mean score of 55.02, tourism protection safety with Garrett mean score of 54.6,the solution of destination marketing with Garrett mean score of 54.55,taxes on product tourism and hospitality providers with Garrett mean score of 51.55, tourism 
globalization with Garrett mean score of 49.56,absent of a national carrier with Garrett mean score of 43.06 and travel marketing with Garrett mean score of 27.26.Meaning inadequate fund for marketing plans is a major challenge in marketing and promoting a destination like Sierra Leone as it was ranked first by respondents.

\section{FINDINGS}

From the above analysis, the following were found out.60\% of the respondents are males, $50 \%$ are in the age bracket between $31-42$ years, $50 \%$ have worked over 10 years, $60 \%$ are holders of first degree, $60 \%$ are from the Ministry of Tourism and Cultural Affairs, $35 \%$ are professionals, $65 \%$ have existed over 15 years, $35 \%$ of their employees are between $21-30$ and $40 \%$ are earning over Le $2,000,000$.It was further found out $60 \%$ of the respondents indicated neutral with regards to the solution of destination marketing, $40 \%$ indicated not satisfactory with tourism infrastructures, $37.5 \%$ indicated highly not satisfactory with globalization, $40 \%$ indicated not satisfactory with taxes, $45 \%$ indicated highly not satisfactory with tourism protection and safety,35\% indicated not satisfactory with travel marketing, $45 \%$ indicated not satisfactory with inadequate fund for marketing plans, 35\% indicated highly not satisfactory with lacked of trained and qualified marketers, $45 \%$ indicated not satisfactory with lacked of marketing strategies and $50 \%$ indicated not satisfactory with absent of a national carrier,

In ranking of the challenges, the Garrett ranking method was used. It was found out that inadequate fund for marketing plans was ranked $1^{\text {st }}$ with Garrett mean score of 55.57 followed by tourism infrastructures 55.5, lacked of trained and qualified marketers 55.34, lacked of marketing strategies 53.02, tourism protection and safety 54.6 , the solution to destination marketing 54.55 , taxes 51.55, tourism globalization 49.56, absent of a national carrier 43.06 and travel marketing 27.26.

\section{CONCLUSION}

Based on the findings, it can be conclude that Sierra Leone cannot attract tourist due to inadequate fund for marketing plans as a major challenge. Without adequate fund both the Ministry of Tourism and Cultural Affairs and National Tourist Board will always be struggling with updating tourism activities in the country, unable to prepare and produce a standard brochure on all the tourist sites and other important information about the country. They are further with tourism infrastructures. Currently, the country is struggling to provide standard infrastructures for the consumption of tourists visiting the country. All the other challenges indicated from the findings can be achieved if there is adequate fund for marketing plans.

\section{RECOMMENDATIONS}

From the conclusion, the following are recommended, the government of Sierra Leone to ensure that adequate funding is provided for the marketing and promotion of the country if it to be a tourist destination.

Government to create an enabling environment for the private sectors to invest in the tourism and hospitality industry which will improve on the quality of tourism infrastructures to meet international standard.

The Ministry of Tourism and Cultural Affairs to strongly collaborate with training institutions offering courses in tourism and hospitality from curriculum development and staff training to ensure the tourism and hospitality is equipped with trained and qualified marketers.

The Ministry of Tourism and Cultural Affairs and National Tourist Board to develop a five- year marketing strategies for the country which can be reviewed as and when the need arise.

It is believed that if tourism is developed in the country one of the challenges is the protection and safety of tourist, in this regard, the government to train and introduce tourist police to be deployed at various tourist sites to ensure their safety is guaranteed.

The Ministry of Tourism and Cultural Affairs and National Tourist Board to engage in wide sensitization in the country about the benefits of tourism to the local people and country as this will help in the marketing of the country.

Finally,government to reconsider the tax policy and if possible give tax waiver to local people who want to invest in the tourism and hospitality industry. This will encourage many investors to invest in the country which lead to quality service delivery.

\section{REFERENCES}

[1] Biganoa et.al (2004) Climate Change and Tourism in the Mediterranean https://www.researchgate.net/publication/24130111

[2] Buhalis, D. (2000). Marketing the competitive destination of the future.

[3] Cameron (2007) Education and Self-Reliance among Care Leavers

[4] Kotler, P., Haider, D. H. \& Rein, I. (1993). Marketing places: Attracting investment, industry, and tourism to cities, states, and nations. New York: The Free Pres

[5] M.Djurica (2010) Tourism Competitiveness and destination branding-A theoretical approach, See discussions, stats, and author profiles for this publication at: https://www.researchgate.net/publication/235899601

[6] Well and Wint (2000) EVALUATING INVESTMENT PROMOTION AGENCIES

[7] Zygmunt (2013) Tourism Destination definition, changes and trends https://www.grin.com/document/381273

\section{AUTHORS}

First Author - Philip Samuel Kongoley - MIH.Milton Margai College of Education and Technology.Faculty of Business Administration and Management, Congo Cross Campus, Freetown Sierra Leone, Email pkongoley@yahoo.com , prkongoley@gmail.com 
International Journal of Scientific and Research Publications, Volume 11, Issue 9, September 2021

This publication is licensed under Creative Commons Attribution CC BY. 